\title{
TANÁRKÉPZÉS EURÓPÁBAN - SZERKEZET ÉS REFORMOK
}

\section{StÉGER CSILla}

az Eötvös Loránd Tudományegyetem Neveléstudományi Doktori Iskolájának

hallgatója

csilla.steger@gmail.com

\begin{abstract}
A tanárképzés az európai uniós közgondolkodásban és a tagországok belpolitikai színterein is az elmúlt tíz évben folyamatosan növekvö figyelmet kapott. A tanárpolitika felértékelödésével párhuzamosan az elmúlt évtizedben az európai felsőoktatást és benne a tanárképzést alapvetöen rajzolta át a bolognai reform. Ezért magából a helyzetből adódó kutatási téma a többciklusú képzési rendszer bevezetésének tanárképzésre gyakorolt hatása, valamint az Európában kialakult tanárképzési szerkezetek összehasonlító vizsgálata. E tanulmány egy 2010-ben végzett európai összehasonlitó vizsgálat eredményét mutatja be, mely a tanárképzés reformjait és szerkezetét vizsgálta 27 országban és annak 29 rendszerében. A magyar tanárképzési szerkezet újabb átalakitásának küszöbén e téma lehetöséget nyújt a jelenlegi, kiinduló állapot európai helyzetkép alapján történö értékelésére.
\end{abstract}

\section{A kutatásról ${ }^{1}$}

Az összehasonlító elemzés tárgya a közismereti tanár- és tanítóképzés volt, mely az ISCED első három ${ }^{2}$ szintjére, vagyis az első osztálytól a tizenkettedik osztályig képez pedagógusokat. A kérdőíves vizsgálat során minisztériumok tanárképzési felelöseit, illetve szakembereit kérdeztük meg az alábbi három témakörről: (1) a tanárképzés föbb jellemzői; (2) a reformok állapota és iránya; (3) a tanárképzési programok szerkezete.

A tanárképzési programok összehasonlíthatósága érdekében a képzési „ösvény” fogalmát vezettük be. Az ösvény egy meghatározott képzés vagy egymást követö képzések együttese, mely tanári szakképzettség megszerzéséhez vezet.

A vizsgálat során az Európai Felsőoktatási Térség (EFT) következő 27 országának minisztériumi felelősei, szakemberei adtak országukról adatokat: Albánia, Ausztria, Belgium, Bosznia és Hercegovina, Csehország, Dánia, Egyesült Királyság (Anglia), Észtország, Finnország, Németország, Hollandia, Horvátország, Izland, Lettország,

\footnotetext{
${ }^{1}$ Köszönetemet szeretném kifejezni témaadó doktori vezetőmnek, Halász Gábornak, továbbá Hunyady Györgynek a szakmai, Münnich Ákosnak a módszertani tanácsaiért és segítségéért.

2 ISCED: Az UNESCO által fejlesztett nemzetközi oktatási besorolási standard (International Standard of Classification of Education), mely szerint az ISCED első szintje az általános iskola alsó tagozata, ISCED második szintje az általános iskola felső tagozata és ISCED harmadik szintje a középiskola.
} 
Lichtenstein, Litvánia, Luxemburg, Magyarország, Moldova, Montenegró, Norvégia, Örményország, Románia, Spanyolország, Svájc, Svédország és Ukrajna.

A továbbiakban bemutatott adatok validitását egyrészt az korlátozza, hogy az EFT országok teljes köréböl nem áll rendelkezésre adat, másrészt a kutatás alapvető módszere, vagyis az, hogy minisztériumi felelősök, szakértők véleményét és szakmai értékelését tükrözi. Bár a felelősök és szakértők az adott ország hivatalos álláspontját voltak hivatottak közvetíteni a kérdőív kitöltésekor, de szubjektív megnyilvánulások is megjelenhettek például az egyéni vélemények országos álláspontként való közvetítésében. Az ilyen torzító elemek kiszürésére a vizsgálat keretében nem nyílt lehetőség.

\section{A tanárképzés főbb jellemzői az Európai Felsőoktatási Térségben}

Ha a jelenlegi európai helyzetképet egy szóval kellene jellemezni, az a változás lenne. Valamennyi vizsgált országban az elmúlt öt évben a tanárképzés átalakult, átalakul. Az országok nagy részében a tanárképzés az átfogó felsőoktatási reformok hatására változott, azonban Ausztria, Belgium (Flandria), Horvátország, Dánia, Izland, Litvánia, Svédország és Anglia esetében a felsőoktatástól elkülönülten, saját szakmai fejlesztési logika szerint.

A reformok országonként természetesen eltérő fázisban vannak. A reformok állapotát mutatja be ISCED szintenként az 1. táblázat.

1. táblázat: A tanárképzési reformok állapota ISCED szintenként

\begin{tabular}{|c|c|c|c|c|}
\hline \multirow[b]{2}{*}{$\begin{array}{c}\text { Az iskolai } \\
\text { szintek }\end{array}$} & \multicolumn{4}{|c|}{ A reformok: } \\
\hline & lezajlottak & $\begin{array}{c}\text { finomhangolás } \\
\text { történik }\end{array}$ & $\begin{array}{l}\text { alapvetö } \\
\text { változások } \\
\text { zajlanak }\end{array}$ & $\begin{array}{c}\text { még most } \\
\text { következnek }\end{array}$ \\
\hline ISCED 1 & $\begin{array}{c}\mathrm{AM}, \mathrm{BE}(\mathrm{Fl}), \mathrm{CZ} \text {, } \\
\mathrm{DK}, \mathrm{FI}, \mathrm{HU}, \mathrm{LU}, \\
\mathrm{ME}, N O, \mathrm{RO}, \mathrm{ES} \text {, } \\
(11 / 28-39 \%)\end{array}$ & $\begin{array}{c}\text { AL, BE(Fr), } \\
\text { BE(G), HR, EE, } \\
\text { DE, MD, NL, CH } \\
(9 / 28-32 \%)\end{array}$ & $\begin{array}{c}\mathrm{AT}, \mathrm{IS}, \mathrm{LV}, \mathrm{LT}, \\
N O, \mathrm{ES} \\
(6 / 28-21 \%)\end{array}$ & $\begin{array}{c}\mathrm{BA}, N L, \mathrm{UA}, \\
\text { GB(E) } \\
(4 / 28-14 \%)\end{array}$ \\
\hline ISCED 2 & $\begin{array}{c}\mathrm{BE}(\mathrm{Fl}), \mathrm{CZ}, \mathrm{DK}, \\
\mathrm{ME}, N O, \mathrm{FI} \\
(6 / 27-22 \%)\end{array}$ & $\begin{array}{c}\mathrm{AL}, \mathrm{AM}, \mathrm{BE}(\mathrm{Fr}), \\
H R, E E, \mathrm{DE}, \mathrm{HU}, \\
\mathrm{MD}, N L, \mathrm{CH}, \mathrm{ES} \\
(11 / 27-41 \%)\end{array}$ & $\begin{array}{l}A T, H R \text {, IS, LV, } \\
\text { LT, LU, NO, RO, } \\
\text { SE (9/27 - 33\%) }\end{array}$ & $\begin{array}{c}A T, \mathrm{BA}, E E, N L \\
\mathrm{UA}, \mathrm{GB}(\mathrm{E}) \\
(6 / 27-22 \%)\end{array}$ \\
\hline ISCED 3 & $\begin{array}{c}\mathrm{BE}(\mathrm{Fl}), \mathrm{CZ}, \mathrm{DK}, \\
\text { FI, ME, CH } \\
(6 / 27-22 \%)\end{array}$ & $\begin{array}{c}\mathrm{AM}, \mathrm{BE}(\mathrm{Fr}), \mathrm{HR}, \\
E E, \mathrm{HU}, \mathrm{MD}, \\
\text { NL, ES } \\
(8 / 27-29 \%)\end{array}$ & $\begin{array}{c}\text { AL, HR, DE, IS, } \\
\text { LV, LT, LU, NO, } \\
\text { RO, SE, } \\
(10 / 27-37 \%)\end{array}$ & $\begin{array}{c}\text { AT, BA, } E E, N O, \\
\text { UA, GB(E) } \\
(6 / 27-22 \%)\end{array}$ \\
\hline
\end{tabular}


Ha ISCED szintenként vizsgáljuk a reformok legjellemzőbb állapotát, akkor egy eltolódás látszik: a reformok alacsonyabb ISCED szinten, vagyis a tanítóképzésben a legelörehaladottabbak, és legkevésbé a középiskolai tanárok képzésében zajlottak le. Ha az országokra koncentrálunk, akkor pedig az tünik ki az adatokból, hogy több ország (a táblázatban dőlve szedve) ISCED szintenként több reformfázisban is található egyszerre, vagyis egyik reformhullám a másikat követi. Ez arra utal, hogy a bolognai ciklusok bevezetésén kívül, vagy azokkal párhuzamosan több ország is tervez és végrehajt alapvető átalakítást. Jellemző azonban, hogy Európa-szerte a strukturális reformok alapvetően lezajlottak, jelenleg az új képzési szerkezetek finomhangolása, illetve tartalmi, szemléleti és szervezeti reformok hullámai érkeznek.

A különböző reformok nagyon hasonló szabályozási környezetben zajlanak. A tanárok végzettségi követelményének meghatározása, a megszerzendő kreditek száma, a tantervek fontosabb összetevői, valamint a tanárképzés kimeneti követelményei, vagyis a tanári kompetenciák a vizsgálat szerint jellemzően központilag (nemzeti vagy az ország berendezkedése szerint tartományi szinten) szabályozottak, míg a tanárképzési kurrikulumokat jellemzően a felsőoktatási intézmények szabadon határozzák meg.

Az adatok szerint a vizsgált országok 79 százaléka alkalmaz a tanárképzési programokra való bejutás előtt valamilyen formában szürést, szelekciót, de csak 45 százalékuknál jelenik meg az alkalmassági szürés a programok vagy a jelentkezői csoportok legalább egy részénél.

A tanárképzési záróvizsgák formája Európa-szerte jellemzően a szakdolgozat, ez alól pusztán Anglia és Horvátország kivétel. Ezen kívül nyolc ország követeli meg a gyakorlati és elméleti stúdiumok eredményeit bemutató portfoliót.

A záróvizsgát követően az oklevél megszerzése a tanárképzés végpontja. A kutatás keretében az oklevéllel szerzett szakképzettséget és végzettségi szintet is vizsgáltuk. Európában a tanárképzési programokban az ISCED első szintjén (vagyis a tanítóképzésben) jellemzően nem szakos szakképzettség szerezhető, hanem osztálytanító jellegü. Az ISCED második és harmadik szintjén, vagyis a felső tagozatos és középiskolai tanárok esetében a szerzett szakképzettség jellemzően egy és kettő, a kétszakosság legerősebben a felsős tanárok szintjén jelentkezik. Általános az az európai gyakorlat, miszerint a képzéstöl, vagy a választott szakképzettségtől függően egy országban egy- és kétszakos tanárok is képződnek. Ettől eltérően a skandináv országok egy részére a három-, sőt négyszakos tanárképzés jellemző. A tanári szakképzettségek száma szerint a vizsgált országok csoportosítását a 2. táblázat tartalmazza. 
2. táblázat: A tanárképzésben szerzett szakképzettségek száma a vizsgált országokban

\begin{tabular}{|c|c|c|c|c|}
\hline \multirow{2}{*}{$\begin{array}{l}\text { Az iskolai } \\
\text { szintek }\end{array}$} & \multicolumn{4}{|c|}{ A képzésben szerzett tanári szakképzettségek száma } \\
\hline & nincs (tanító) & egy & kettö & $\begin{array}{c}\text { kettönél } \\
\text { több }\end{array}$ \\
\hline ISCED 1 & $\begin{array}{c}\text { AL, AM, A, B(Fl), } \\
\text { B(Fr), B(G), BIH, } \\
\text { HR, CZ, EST, FIN, } \\
\text { G, HU, LV, LI, LT, } \\
\text { L, MD, CG, NL, } \\
\text { RO, S, CH, UA, UK } \\
\quad(25 / 29-86 \%)\end{array}$ & $\begin{array}{c}\mathrm{A}, \mathrm{BIH}, \mathrm{HR}, \mathrm{G}, \mathrm{IS}, \\
\mathrm{E},(6 / 29-20 \%)\end{array}$ & $\begin{array}{l}\text { BIH, DK, G, IS } \\
(4 / 29-13 \%)\end{array}$ & $\begin{array}{c}\text { DK, N } \\
(2 / 29-7 \%)\end{array}$ \\
\hline ISCED 2 & $\begin{array}{c}\text { HR } \\
(1 / 28-3 \%)\end{array}$ & $\begin{array}{l}\text { AM, A, B(Fr), BIH, } \\
\text { HR, CZ, EST, FIN, } \\
\text { HU, IS, LV, LT, L, } \\
\text { MD, CG, NL, RO, } \\
\text { E, UA, UK(E) } \\
(20 / 28-71 \%)\end{array}$ & $\begin{array}{c}\text { AL, AM, A, B(Fl), } \\
\text { B(Fr), BIH, HR, } \\
\text { CZ, DK, EST, FIN, } \\
\text { G, HU, IS, LV, LI, } \\
\text { LT, MD, N, RO, } \\
\text { CH, UA, UK(E) } \\
(23 / 28-82 \%)\end{array}$ & $\begin{array}{c}\mathrm{B}(\mathrm{Fr}), \mathrm{DK}, \\
\mathrm{LI}, \mathrm{N}, \mathrm{S} \\
\mathrm{CH} \\
(6 / 28-21 \%)\end{array}$ \\
\hline ISCED 3 & - & $\begin{array}{c}\text { AL, AM, B(Fl), } \\
\text { BIH, HR, CZ, EST, } \\
\text { FIN, HU, IS, LV, } \\
\text { LI, LT, L, MD, CG, } \\
\text { NL, N, RO, E, CH, } \\
\text { UA UK(E) } \\
(23 / 28-82 \%)\end{array}$ & $\begin{array}{c}\text { AM, A, B(Fl), BIH, } \\
\text { HR, CZ, DK, EST, } \\
\text { FIN, G, HU, LV, } \\
\text { LI, LT, MD, N, RO, } \\
\text { S, CH, UA, UK(E) } \\
(21 / 28-75 \%)\end{array}$ & $\begin{array}{c}\mathrm{B}(\mathrm{Fr}) \\
(1 / 28-3 \%)\end{array}$ \\
\hline
\end{tabular}

A vizsgálatból arra is fény derült, hogy Angliában, Belgium francia nyelvű közösségében, Izlandon, Spanyolországban és Svédországban a megszerzett tanári szakképzettség nem feltétlenül határozza meg az oktatott tantárgyat, vagyis például egy nyelvtanár nem feltétlenül csak nyelvet taníthat. Ez a rugalmasság utalhat arra, hogy ezen országokban a tanár tanulást támogató szerepe a diszciplináris szaktudásnál nagyobb hangsúlyt kap, és arra is, hogy a tudás, a logikai és kommunikációs készségek tantárgyi irányultságok között transzferálhatók.

A 3. táblázat mutatja be országonként a tanári munkakör betöltéséhez elvárt végzettségi szinteket az oktatási rendszer különböző szintjein. 
3. táblázat: A tanári munkakör betöltését lehetővé tevő végzettségi szintek a vizsgált országokban

\begin{tabular}{|c|c|c|c|c|}
\hline \multirow[b]{2}{*}{$\begin{array}{c}\text { Az iskolai } \\
\text { szintek }\end{array}$} & \multicolumn{4}{|c|}{ Tanári munkakör betöltését lehetővé tevö szintek } \\
\hline & $\begin{array}{c}\text { nem } \\
\text { felsöfokú }\end{array}$ & $\begin{array}{l}\text { alapképzési } \\
\text { szint }\end{array}$ & $\begin{array}{l}\text { mesterképzési } \\
\text { szint }\end{array}$ & $\begin{array}{c}\text { szakirányú } \\
\text { posztgraduális } \\
\text { képzés }\end{array}$ \\
\hline ISCED 1 & $\begin{array}{c}\text { AM, MD } \\
(2 / 29-7 \%)\end{array}$ & $\begin{array}{c}\text { AL, AT, BE(Fl), } \\
\text { BE(Fr), BE(G), BA, } \\
\text { DK, HU, LV, LI, LT, } \\
\text { LU, MD, ME, NL, NO, } \\
R O, \mathrm{ES}, \mathrm{CH}, U A, \mathrm{~GB}(\mathrm{E}) \\
(21 / 29-72 \%)\end{array}$ & $\begin{array}{c}\text { HR, CZ, EE, FIN, } \\
\text { DE, IS, } M D, N O, \\
\text { RO, SE, } U A \\
(11 / 29-38 \%)\end{array}$ & - \\
\hline ISCED 2 & $\begin{array}{c}\text { MD } \\
(1 / 29-3 \%)\end{array}$ & $\begin{array}{c}\mathrm{AM}, \mathrm{AT}, \mathrm{BE}(\mathrm{Fl}), \\
\mathrm{BE}(\mathrm{Fr}), \mathrm{BE}(\mathrm{G}), \mathrm{BA}, \\
\mathrm{DK}, H U, \mathrm{LV}, L I, \mathrm{LT}, \\
M D, \mathrm{ME}, \mathrm{NL}, N O, \\
\mathrm{RO}, U A, \mathrm{~GB}(\mathrm{E}) \\
(18 / 29-62 \%)\end{array}$ & $\begin{array}{c}\mathrm{AL}, \mathrm{AT}, \mathrm{HR}, \mathrm{CZ}, \\
\mathrm{EE}, \mathrm{FI}, \mathrm{DE}, H U, \\
\mathrm{IS}, \mathrm{LV}, L I, \mathrm{LU}, \\
M D, N O, \mathrm{ES}, \mathrm{SE}, \\
\mathrm{CH}, U A \\
(18 / 29-62 \%)\end{array}$ & - \\
\hline ISCED 3 & $\begin{array}{c}\text { MD } \\
(1 / 29-3 \%)\end{array}$ & $\begin{array}{l}\mathrm{AM}, \mathrm{BA}, \mathrm{LV}, L I, \mathrm{LT} \text {, } \\
M D, \mathrm{ME}, N O, R O, U A \text {, } \\
\mathrm{GB}(\mathrm{E}) \\
(11 / 29-38 \%)\end{array}$ & $\begin{array}{c}\mathrm{AL}, \mathrm{AT}, \mathrm{BE}(\mathrm{Fr}), \\
\mathrm{BE}(\mathrm{G}), \mathrm{HR}, \mathrm{CZ}, \\
D K, \mathrm{EST}, \mathrm{FI}, \mathrm{DE}, \\
\mathrm{HU}, \mathrm{IS}, \mathrm{LV}, L I, \mathrm{LU}, \\
M D, \mathrm{NL}, N O, R O, \\
\mathrm{ES}, \mathrm{SE}, C H, U A \\
(23 / 29-79 \%)\end{array}$ & $\begin{array}{c}\mathrm{BE}(\mathrm{Fl}), D K, \\
C H \\
(3 / 29-10 \%)\end{array}$ \\
\hline
\end{tabular}

A vizsgált országok közül mindössze kettőben lehetséges felsőfokú végzettség hiányában tanári munkakört betölteni. Alsó tagozatos tanárok esetében Európában domináns végzettségi követelmény a bachelor, vagyis az alapképzési szint, felső tagozatos tanárok esetében az alap- és mesterfokozat egyformán elfogadott és követelt, míg a középiskolai tanároknak jellemzően mesterképzési szintủ oklevéllel kell rendelkezniük. A táblázatban kiemelten szerepelnek azon országok betüjelei, melyek egy meghatározott iskolatípusban betöltött munkakör esetén több tanári végzettségi szintet is elfogadnak.

A vizsgált országok 52 százalékában a tanári munkakörben való alkalmazás további feltétele a tanári jogosultsággal való rendelkezés. A tanári jogosultság az oklevéllel együtt szerezhető meg kilenc országban, hat országban pedig a bevezető szakasz sikeres teljesítésével. A tanári jogosultság bevezetésére két ország kivételével a tanári munkakörök teljes körében (tanító, felső tagozatos és középiskolai tanár) egységesen került sor. 
Összefoglalva elmondható, hogy az európai tanárképzési rendszerek történeti, kulturális, társadalmi és gazdasági okokra is visszavezethetỏen színes mozaikot alkotnak. Az eltérések ellenére vannak azonban közös jellemzőik, melyek közül talán a legfontosabb a folyamatos változás. A reformok, komplex célrendszerük miatt egy lépés helyett több szakaszban, hullámokban jöttek és jönnek. A bolognai reform strukturális változásai a tanítóképzésben zajlottak le a leggyorsabban és a középiskolai tanárképzésben a leglassabban. Az alapvető (szerkezeti) változások az országok döntő többségében már lezajlottak, legjellemzőbb jelenleg a megvalósult reformok finomhangolása. További közös trend, hogy az iskolarendszer szintjeivel együtt a tanároktól elvárt végzettségi követelmény szint is emelkedik. Ez arra utal, hogy az európai országokban a magasabb minőségủ tanulás-tanítás megvalósítása a mesterszintü végzettség keretében látszik biztosítottnak a hosszabb képzési idő és a jelentkezők erősebb motivációja miatt.

\section{A tanárképzési reformok és azokban a bolognai folyamat jelentősége}

A tanárképzési rendszerek reformjainak vizsgálata lehetőséget nyújt a pillanatnyi rendszerjellemzők fejlődési, változási irányának azonosítására és az azok mögött húzódó motivációk megismerésére.

A vizsgálat során három ország (Ausztria, Litvánia és Svédország) kivételével, 26 ország válaszolta azt, hogy számára a tanárképzési reformok alakulásában a bolognai folyamat releváns volt. Ezen országok számára bolognai folyamat különböző vonásaiból a legfontosabb az európai dimenzió, (vagyis az oklevelek elismerése), a magasabb szintü oktatáspolitikai kooperáció, valamint a három ciklus, az alap-, mester- és doktori képzés bevezetése volt.

A megvalósult reformok hivatalos céljainak bemutatásakor a legtöbb (legalább hat) ország említette a bolognai reform megvalósítását, a kutatáson alapuló tanulás, más szóval az osztálytermi kutatások előmozdítását, valamint a tanárképzés átfogó minőségének javítását, öt-öt ország pedig az ismeretorientált oktatás helyett a kompetencia orientált tanítás terjesztését, a gyakorlati felkészítés erősítését és a tanári végzettség magasabb szintre emelését.

A vizsgálat során a nyílt kérdéseket követően a változások egyes megadott mozgatórugóinak fontosságára konkrétan rákérdeztünk (0: nem releváns - 5: a legfontosabb). Az 1. ábra tartalmazza a megadott tényezők vonatkozásában a fontosság európai átlagát. 


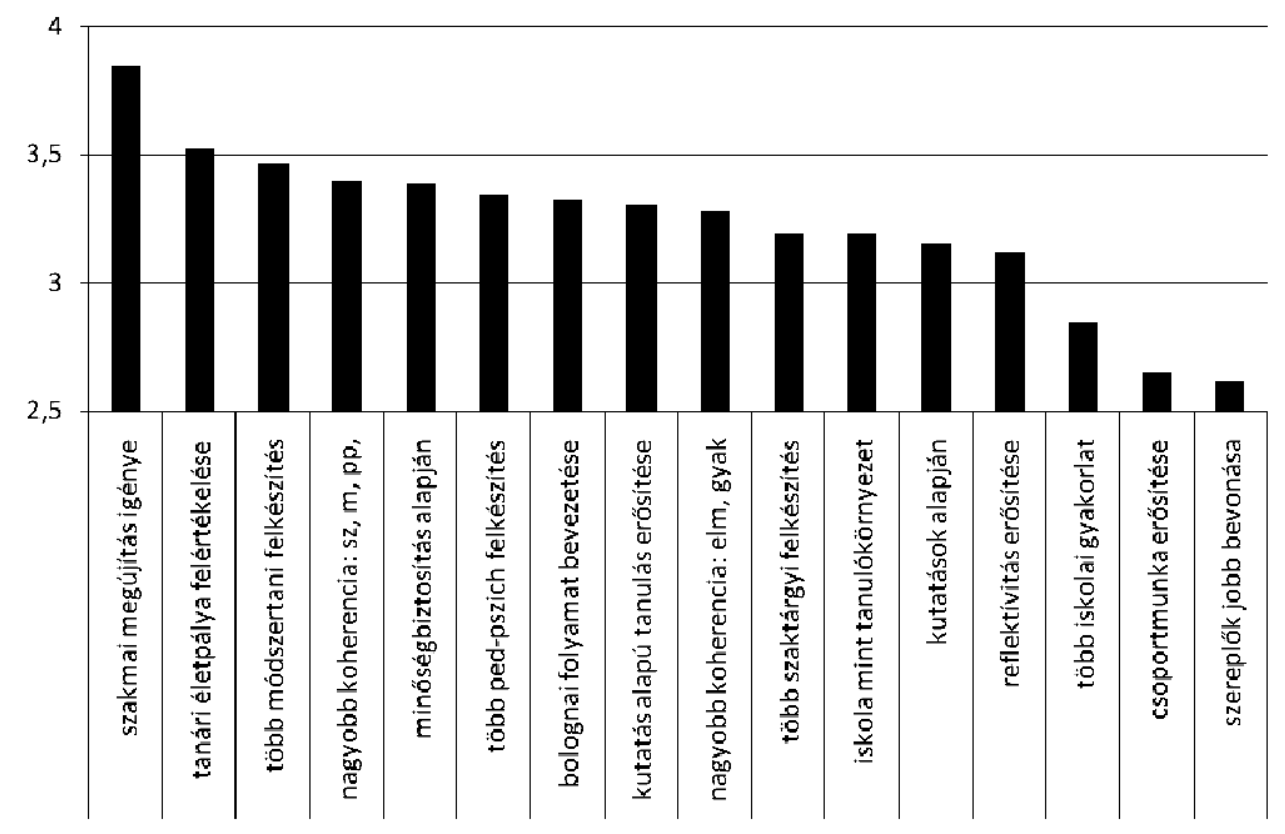

1. ábra: A tanárképzési reformok mozgatórugói fontosságuk átlaga szerint (0: nem releváns - 5: a legfontosabb)

Az ábrából kiderül, hogy a változások legfontosabb mozgatórugója a szakmai megújítás igénye $(3,85)$ volt Európa-szerte, ezt követi a tanári életpálya felértékelése $(3,52)$, valamint a módszertani felkészítés erősítése $(3,4)$. A bolognai folyamat bevezetése a középmezőnyben, míg a hazai diskurzusokban előtérbe kerülő szaktárgyi felkészítés erősítése mindössze 10. helyen szerepe az európai országokban a reformokat meghatározó tényezők között. A válaszoló országok szerint a változásokat legkevésbé az iskolai gyakorlat növelésének (2,85 átlag fontosság), a csoportmunka fejlesztésének $(2,65)$ és az oktatáspolitikai szereplők (stakeholderek) bevonásának igénye $(2,62)$ befolyásolta.

A kulcsszereplők szélesebb körü bevonására pedig úgy tünik lett volna tér. A felsőoktatási intézmények oktatóinak és a kormányzati, minisztériumi munkatársaknak a részvétele a reformok elömozditásában általános. Azonban a válaszoló országoknak kevesebb mint felében álltak a változtatások mögött kezdeményezőként az iskolák (11/27), a szakértők és a szakmai szervezetek (hét országban), minőségbiztosítási ügynökségek (ötben), valamint szülöi és diák szervezetek (mindössze négy országban).

A felmérésben szereplő országok a tervezett változások és reformok kérdésében nagyon eltérő válaszokat adtak. A pedagógusképzésben a didaktikai, a pedagó- 
giai, vagyis a tanári felkészítés erősítését 29 országból öt, a tanári kompetenciák hatékonyabb elsajátíttatását pedig négy ország jelölte meg mint a következő reformok célját. Mindkét irány azt a meggyőződést sugallja, hogy a tanárképzés minősége a szaktárgyi ismeretek helyett a tanulási-tanítási folyamatra való fokozottabb figyelemmel biztosítható. A megkérdezett 29 ország 65 százalékának van tanárképzési stratégiája.

Összefoglalva, a gyüjtött adatokból kiolvasható, hogy a tanárképzési reformokban, bár a bolognai folyamat szerepet játszott, az alapvető tartalmakat mégis a fejlödés, a változás országonként sajátos útjai, belső irányai egyedileg szabták meg. A bolognai folyamat a strukturális átalakítással lehetőséget nyújtott arra, hogy az egyes nemzeti rendszerek a tanárképzés minőségét, szakmaiságát megújítsák, a tanári pálya presztízsét növeljék. Az utóbbit az európai országok többségében a tanári kompetenciák hatékonyabb fejlesztésével, a tanárságra való felkészítés erősítésével gondolták és gondolják megvalósítani. A tanárképzési reformokban az iskolák és egyéb társadalmi szereplők alacsony szerepvállalása, illetve bevonása arra enged következtetni, hogy a növekvő figyelem és az oktatáspolitikai szerep növekedése ellenére a tanárképzés a legtöbb országban továbbra sem valamennyi érintett bevonásával, vagy társadalmi konszenzussal irányított terület, hanem a szaktárca és a felsőoktatás szűk szakmai ügye.

\section{A tanári oklevélhez vezető tanulmányi ösvények tartalma és szerkezete}

Az elvégzett európai kutatás harmadik fő pillére az európai országok által nyújtott tanárképzési programok szerkezeti, tartalmi összevetése volt a bolognai átalakulásokat követően. Ennek érdekében a tanítók, a felső tagozatos és a középiskolai közismereti tanárok képzésével kapcsolatban az országok képviselőit arra kértük, hogy mutassák be az oklevélszerzéshez vezető tanulmányi ösvényeiket.

Az ösvény a tanári szakképzettség megszerzéséhez vezető tanulmányi út, mely egy vagy több, egymásra épülő felsőfokú képzésből áll. A vizsgálat keretében a tanárrá válás különböző útjait külön ösvényként kértük feltüntetni, ezért nemcsak a 18 évesek számára nyújtott, érettségire épülő tanárképzési programok köre került vizsgálatra, hanem a diszciplináris oklevél birtokában, a későbbi karrier módosítás

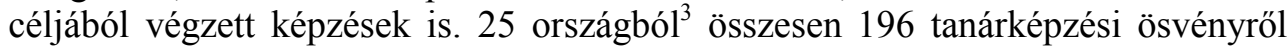
érkezett adat a vizsgálat során. Valamennyi ösvény tekintetében a nemzeti szakértők megadták az ösvény képzési szerkezetét, a teljes hosszát és a megszerzendő kreditek számát.

\footnotetext{
${ }^{3}$ Albánia, Ausztria, Belgium (Fl), Belgium (Fr), Belgium (G), Bosznia és Hercegovina, Csehország, Dánia, Észtország, Finnország, Hollandia, Horvátország, Izland, Lettország, Luxemburg, Magyarország, Moldova, Montenegró, Németország, Norvégia, Örményország, Románia, Spanyolország, Svájc, Svédország és Ukrajna.
} 
Az ösvényeket szerkezetük alapján klaszteranalízis segítségével csoportosítottuk. A 4. táblázat tartalmazza az ösvények képzési szerkezetét klaszterenként és ISCED szintenként.

4. táblázat: Az ösvények számossága ISCED szintenként és szerkezet szerint

\begin{tabular}{|c|c|c|c|c|c|}
\hline \multicolumn{2}{|c|}{$\begin{array}{c}\text { Az ösvény során szerzett } \\
\text { végzettség(ek) }\end{array}$} & ISCED 1 & ISCED 2 & ISCED 3 & Összesen \\
\hline$B$ & $\begin{array}{c}\mathrm{B}, \mathrm{B}+\mathrm{Sz}, \mathrm{F}, \\
\text { nem FO }\end{array}$ & 28 & 27 & 14 & 69 \\
\hline$B+M$ & $\begin{array}{c}\mathrm{B}+\mathrm{M}, \\
\mathrm{B}+\mathrm{M}+\mathrm{M} / \mathrm{Sz}\end{array}$ & 13 & 36 & 46 & 95 \\
\hline$M$ & $\begin{array}{c}\mathrm{M}, \mathrm{M}+\mathrm{Sz}, \mathrm{E}, \\
\mathrm{M}+\mathrm{M} / \mathrm{B}\end{array}$ & 7 & 12 & 13 & 32 \\
\hline \multicolumn{2}{|c|}{ Osszzesen: } & 48 & 75 & 73 & 196 \\
\hline
\end{tabular}

Jelmagyarázat: B: bachelor, M: mester, Sz: szakirányú továbbképzés, F: főiskolai oklevél, E: egyetemi oklevél, nem FO: középiskolára épülő, de nem felsőoktatási képzés

A 4. táblázatból látszik, hogy a 25 ország 48 ösvényt kínál a tanítóknak, míg nagyságrenddel többet (73-t, illetve 75-t) a felső tagozatos és középiskolai tanárok számára, tehát az ösvények közötti választási lehetőség jóval tágabb az utóbbi két szinten tanítani szándékozók számára. A táblázatból kiolvasható, hogy ISCED szintenként három alapvető csoportba soroltuk az ösvényeket szerkezetük szerint. Az első, melynek hívószava a bachelor, vagyis az alapképzés (jele B). Ebbe a csoportba tartoznak a föiskolai, a nem felsőoktatási, az alapképzési, valamint az alapképzésre épülő szakirányú továbbképzési szinteket tartalmazó ösvények. A második klaszterbe (jele: $B+M)$ az alapvetően kétciklusú vagy konszekutív képzések kerültek, vagyis a bachelor plusz mester struktúrájúak, valamint az e két ciklust (az életpálya korrekció esetében) mesterképzéssel vagy szakirányú továbbképzéssel kiegészítő ösvények. A harmadik csoport (jele: M) az osztatlan képzéseké, illetve az arra épülő ösvényeké. Ide tartoznak a vizsgálat idején még fennmaradt egyetemi képzések, az osztatlan mesterek, valamint az ezekre épülő mester-, alap- vagy szakirányú továbbképzést magában foglaló ösvények.

Az adatokból kiderül, hogy a tanárképzési programok jellemző struktúrája Európában a kétciklusú, osztott képzés, vagyis az egymásra épülő, konszekutív szerkezet. Az összes ösvény több mint fele, 95 ösvény tartozik a kétciklusú csoportba, míg a bolognai első ciklusba az első csoport 69 képzéséből (a két nem felsőoktatási és három föiskolai képzést levonva) 64. E két domináns csoporthoz képest markánsan kevesebb, 32 osztatlan képzést magába foglaló ösvény van a vizsgált országokban. ISCED szintenként jól mutatja az eltérő szerkezetü képzések arányait a 2. ábra. 


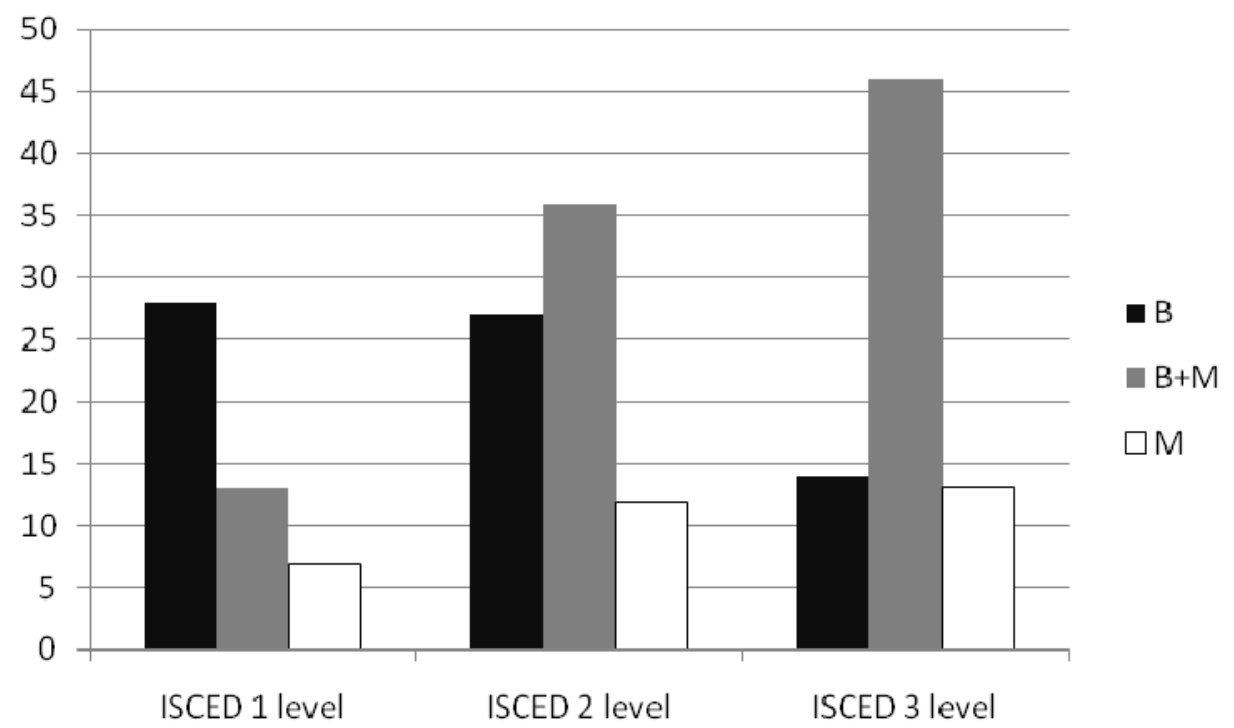

2. ábra: ISCED szintenként a tanárképzési ösvények száma szerkezet szerint

Elmondható tehát, hogy a tanítókat jellemzően az alapképzésben, a felső tagozatos és középiskolai tanárokat pedig az alapképzésre épülő mesterképzési struktúrában képzik az európai országok. Fontos megjegyezni, hogy a vizsgálatban szereplö országok 52 százaléka képezi a felső tagozatos és a középiskolai tanárokat együtt, míg az országok 32 százalékában van olyan ösvény, mely a két tanár csoport számára közös, de van olyan is, mely különbözö. Mindössze a vizsgált országok 16 százalékában vélik úgy, hogy a felső tagozatos és a középiskolai tanárok képzése annyira különbözö, hogy nincs számukra közös ösvény.

A vizsgálat során a tanárképzési ösvényekről a szerkezeten kívül további adatokat is gyüjtöttünk. Az ösvény hossza és az összegyüjtendő kreditek száma valamennyi képzés esetén rendelkezésre állt, míg a képzés belső tartalmára vonatkozó adatok közül (pedagógiai és pszichológiai, szaktárgyi, szakmódszertani, iskolai gyakorlati, szakdolgozati és egyéb kreditek száma) jellemzően a gyakorlatra és a szaktárgyi ismeretekre fordított kreditek száma volt egyértelmủen azonosítható. Terjedelmi okokból eltekintünk ISCED szintenként a képzési struktúra szerint kialakított ösvény klaszterek eltérő jellemzőinek bemutatásától, pusztán a jellemzőknek az összes ösvény alapján képzett átlag értékeivel foglalkozunk. Ezeket mutatja az 5. táblázat. 
5. táblázat: ISCED szintenként a tanárképzési ösvények jellemzői

\begin{tabular}{|l|c|c|c|c|c|c|c|}
\hline & $\begin{array}{c}\text { Ösvények } \\
\text { száma }\end{array}$ & $\begin{array}{c}\text { Domináns } \\
\text { szerkezet }\end{array}$ & $\begin{array}{c}\text { Hossz } \\
\text { átlaga } \\
(\dot{e} v)\end{array}$ & $\begin{array}{c}\text { ECTS } \\
\text { kredit } \\
\text { átlag }\end{array}$ & $\begin{array}{c}\text { Összes } \\
\text { szakos } \\
\text { kredit átlag }\end{array}$ & $\begin{array}{c}\text { Összes } \\
\text { nem szakos } \\
k r \text { átlag }\end{array}$ & $\begin{array}{c}\text { Gyakorlati } \\
\text { kredit átlag }\end{array}$ \\
\hline ISCED 1 & 48 & $\mathrm{~B}$ & 4,2 & 253 & 139 & 114 & 31 \\
\hline ISCED 2 & 75 & $\mathrm{~B}+\mathrm{M}$ & 4,7 & 283 & 177 & 106 & 26 \\
\hline ISCED 3 & 73 & $\mathrm{~B}+\mathrm{M}$ & 5,1 & 310 & 205 & 105 & 26 \\
\hline
\end{tabular}

A tanítóképzés esetén, mint már említettük a domináns ösvény struktúra az alapképzés, melynek hossza átlagosan 4,2 év, ennek megfelelően az összes kredit száma átlagosan $253^{4}$. Ebből a diszciplináris tanulmányokra jutó kreditek száma átlagosan 139, és közel ugyanennyi, 114 kredit a többi, jellemzően pedagógiai és pszichológiai, módszertani és egyéb kreditek átlaga a gyakorlattal együtt. Az iskolai gyakorlat a vizsgált 25 országban átlagosan 31 kredit a tanítóképzésben.

A felső tagozatos és a középiskolai tanárok képzése ettől szerkezetében és belső arányaiban is erősen eltér. A szerkezetben a domináns modell a konszekutív alapképzésre épülő mesterképzés, a képzés hossza pedig öt év körüli. A megszerzendő kreditekből jóval több jut a szaktárgyi ismeretekre, a középiskolai tanárképzés esetén ez a képzés kétharmadát adja. A pedagógiai és pszichológiai, módszertani és egyéb kreditek a tanítóéhoz képest alacsonyabbak, de a 100 kreditet meghaladják. Az iskolai gyakorlatra fordított kreditek szintén alacsonyabbak a tanítóképzési átlagnál, de a fél éves, 30 kredites mennyiséget alulról közelítik.

A hazai tanárképzés bolognai átalakulásának újra éledt vitájában releváns lehet a tanári mesterszak európai trendekhez hasonlítása, jellemzőinek az európai átlagokkal való összevetése. Ezt tartalmazza a 6. táblázat.

A magyarországi tanári mesterszakról a fenti összevetés alapján elmondható, hogy az európai középiskolai ösvények átlagánál is igényesebb, pedig nemcsak középiskolai, hanem felső tagozatos általános iskolai tanárokat is képez. Hosszban az európai átlagon túlmutat, a szaktárgyi ismeretek szempontjából több mint 30 kredittel erősebb, így biztosít alapos felkészülést, az iskolai gyakorlata pedig az átlagnak megfelelő, azt enyhén meghaladó. Pusztán egy szempontból marad el az európai átlagtól, a szaktárgyon kívüli pedagógia és pszichológiai, módszertani és egyéb felkészítés szempontjából.

\footnotetext{
${ }^{4}$ Valamennyi vizsgált országban bevezetésre került az ECTS (European Credit Transfer System), mely egy tanév alatt 60 kredit hallgatói munkamennyiséget ért.
} 
6. táblázat: A tanári mesterszak és az európai középiskolai ösvények jellemzőinek összevetése

\begin{tabular}{|l|c|c|c|c|c|c|c|}
\hline & $\begin{array}{c}\text { Ösvények } \\
\text { száma }\end{array}$ & $\begin{array}{c}\text { Domináns } \\
\text { szerkezet }\end{array}$ & $\begin{array}{c}\text { Hossz } \\
\text { átlaga } \\
(\text { év) }\end{array}$ & $\begin{array}{c}\text { Összes } \\
\text { kredit }\end{array}$ & $\begin{array}{c}\text { Összes } \\
\text { szakos } \\
\text { kredit }\end{array}$ & $\begin{array}{c}\text { Osszes } \\
\text { nem szakos } \\
\text { kredit }\end{array}$ & $\begin{array}{c}\text { Gyakorlati } \\
\text { kredit }\end{array}$ \\
\hline $\begin{array}{l}\text { ISCED 3 } \\
\text { Európai átlag }\end{array}$ & 73 & $\mathrm{~B}+\mathrm{M}$ & 5,1 & 310 & 205 & 105 & 26 \\
\hline $\begin{array}{l}\text { tanári } \\
\text { mesterszak }\end{array}$ & 1 & $\mathrm{~B}+\mathrm{M}$ & 5,5 & 330 & 236 & 94 & 30 \\
\hline
\end{tabular}

Összefoglalva elmondható, hogy a vizsgált európai országokban a bolognai típusú képzési struktúra, az alapképzés, illetve a kétciklusú alap- és mesterképzés a domináns modell. A tanítók esetében az alapképzés, a tanárok esetében az osztott képzés a jellemző. A bolognai folyamat keretében hazánkban bevezetésre került tanári mesterszak az európai középiskolai tanárképzési átlaghoz mérten is igényes, szaktárgyi felkészítése kifejezetten erős, az európai átlagtól a pedagógiai és pszichológiai területen marad el. A vizsgált 25 európai országnak pusztán 16 százalékában válik szigorúan ketté az általános iskolai és a középiskolai tanárképzés.

\section{Konklúziók}

Az európai vizsgálat eredményei szerint a bolognai folyamat teljes felsőoktatásra kiterjedő szerkezet átalakítása lehetőséget jelentett a tanárképzési programok organikus fejlődésének továbbvitelére. A bolognai folyamathoz kapcsolódó tanárképzési változások hullámokban zajlottak és zajlanak, de általános értelemben véve Európában a struktúra váltás nagy hulláma véget ért, jelenleg a finomhangolás, illetve a tartalmi, hatékonyság növelő reformokra helyeződött át a hangsúly.

Úgy tünik, hogy a hazai bolognai tanárképzési reform az európai irányoknak megfelelően, azzal időben és tartalomban is összhangban haladt. Az összehasonlító elemzések alapján megállapítható, hogy a hazai tanárképzés az átlagosnál igényesebb szakterületi felkészítést és iskolai gyakorlatot biztosít. A jelenlegi európai trendek nem támasztják alá azt, a szakemberek egy részénél megjelenő igényt, hogy az osztott képzésről visszatérjünk az osztatlanra, valamint, hogy szétválasszuk az általános iskolai és középiskolai tanárképzést.

\section{Irodalom}

ATEE (2007): "Response to the Commission's public consultation on schools for the 21st century". ATEE.

URL: http://www.atee1.org/publications/3/response_to_the_commission_039_s_public_ consultation_on_schools_for_the_21st_century 
ATEE (2005): “The Quality of Teachers”. ATEE.

URL: http://www.atee1.org/publications/2/the_quality_of_teachers

OECD (2005): “Teachers Matter - Attracting, Developing and Retaining Effective Teachers". OECD Publishing.

URL: http://www.oecd.org/document/52/0,3746,en_2649_39263231_34991988_1_1_1_1, 00.html

Collahan, J. (2002): "Teacher Education and the Teaching Career in an Era of Lifelong Learning". OECD Education Working Paper, No. 2, OECD Publishing.

URL: http://www.oecd-ilibrary.org/education/teacher-education-and-the-teaching-careerin-an-era-of-lifelong-learning_226408628504

Council Conclusions (2009): "Council Conclusions on the professional development of teachers and school leaders". European Commission.

URL: http://register.consilium.europa.eu/pdf/en/09/st15/st15098.en09.pdf

Council Conclusions (2008): “Council Conclusions on preparing young people for the $21^{\text {st }}$ century: an agenda for European cooperation on schools". European Commission. URL: http://www.consilium.europa.eu/uedocs/cms_Data/docs/pressdata/en/educ/104238. pdf

Council Conclusions (2007): "Conclusions of the Council and of the Representatives of the Governments of the Member States, meeting within the Council of 15 November 2007, on improving the quality of teacher education". European Commission.

URL: http://eur-lex.europa.eu/LexUriServ/LexUriServ.do?uri=OJ:C:2007:300:0006:0009: EN:PDF

Dimitropoulos, A. (2008): “The Bologna process and teacher education structures in Europe: Creating a European Teacher Education Area”. ENTEP.

URL: http://entep.unibuc.eu/papers.php

ETUCE (2008): “The Quality of Teacher Education, policy paper from the European Teacher Unions". ETUCE.

URL: http://etuce.homestead.com/Publications2008/ETUCE_PolicyPaper_en_web.pdf

Eurydice (2009): "Key Data on Education in Europe 2009". Education, Audiovisual and Culture Executive Agency.

URL: http://eacea.ec.europa.eu/education/eurydice/documents/key_data_series/105EN.pdf

Eurydice (2005): "Reforms of the teaching profession: a historical survey (1975-2002)". Topics in education in Europe, Vol. 3, The Teaching profession in Europe: Profile, Trends and Concerns, Directorate-General for Education and Culture.

URL: http://eacea.ec.europa.eu/education/eurydice/thematic_studies_archives_en.php

McKinsey\&Company (2011): "How the world's most improves school systems keep getting better". McKinsey\&Company.

URL: http://ssomckinsey.darbyfilms.com/reports/schools/How-the-Worlds-MostImproved-School-Systems-Keep-Getting-Better_Download-version_Final.pdf 
McKinsey\&Company (2007): "How the world's best performing school systems come out on top”. McKinsey\&Company.

URL: http://www.mckinsey.com/App_Media/Reports/SSO/Worlds_School_Systems_ Final.pdf

Musset, P. (2010): "Initial Teacher Education and Continuing Training Policies in a Comparative Perspective: Current Practices in OECD Countries and a Literature Review on Potential Effects”. OECD Education Working Papers, No. 48, OECD Publishing. doi: $10.1787 / 5 \mathrm{kmbphh} 7 \mathrm{~s} 47 \mathrm{~h}$-en

Schratz, M. (2005): “What is the European teacher? A Discussion Paper of the European Network of Teacher Education”. ENTEP.

URL: http://www.see-educoop.net/education_in/pdf/workshop/tesee/dokumenti/europeanteacher.pdf

University of Yväskylä (2010): “Teacher Education Curricula in the EU”. University of Yväskylä. URL: http://peda.net/veraja/jyu/uniservices/teacher 